PACS numbers: 87.23._n, 89.60._k , 07.88._y

\title{
ANALYSIS AND FORECAST OF THE ENVIRONMENTAL RADIOACTIVITY DYNAMICS BASED ON METHODS OF CHAOS THEORY: GENERAL SCHEME AND SOME APPLICATION
}

\author{
A.V. Glushkov, Dr. Sci. (Phys.-Math.) \\ E.R. Gubanova, Dr. Sci. (Econ.) \\ O.Yu.Khetselius , Dr. Sci. (Phys.-Math.) \\ G.P. Prepelitsa, Dr. Sci. (Phys.-Math.) \\ A.A. Svinarenko, Dr. Sci. (Phys.-Math.) \\ Yu.Ya.Bunyakova, Cand.Sci. (Geogr.) \\ V.V. Buyadzhi, Assoc.-Lect. \\ Odessa State Environmental University, 15 , \\ LvivskaSt., 65016 Odessa,Ukraine, glushkovav@gmail.com
}

\begin{abstract}
We present firstly a new whole technique of analysis, processing and forecasting environmental radioactivity dynamics, which has been earlier developed for the atmospheric pollution dynamics analysis and investigation of chaotic feature sin dynamics of the typical hydroecological systems. The general formalism include: a). A general qualitative analysis of dynamical problem of the environmental radioactivity dynamics (including a qualitative analysis from the viewpoint of ordinary differential equations, the "Arnold-analysis"); b) checking for the presence of a chaotic (stochastic) features and regimes (the Gottwald-Melbourne's test; the method of correlation dimension); c) Reducing the phase space (choice of the time delay, the definition of the embedding space by methods of correlation dimension algorithm and false nearest neighbor points); d). Determination of the dynamic invariants of a chaotic system (Computation of the global Lyapunov dimension $\lambda_{\alpha}$; determination of the Kaplan-York dimension $d_{L}$ and average limits of predictability $\operatorname{Pr}_{\max }$ on the basis of the advanced algorithms; e) A non-linear prediction (forecasting) of an dynamical evolution of the system. The last block indeed includes new (in a theory of environmental radioactivity dynamics) methods and algorithms of nonlinear prediction such as methods of predicted trajectories, stochastic propagators and neural networks modelling, renorm-analysis with blocks of the polynomial approximations, wavelet-expansions etc.

Key words: environmental radioactivity dynamics, the ecological state, time series of concentrations, pollutants, analysis and prediction methods of the theory of chaos.
\end{abstract}

\section{INTRODUCTION}

One of the most actual and important problem of the applied ecology and environment protection is connected with correct quantitative description of environmental radioactivity dynamics (look for example, [1,2]). Usually one should note the following actual problems such as long-term investigation of the behavior of radionuclides in the environment, elucidation of the mechanism of transfer of radionuclides in the environment to animals through the food chain, elucidation of the mechanism of transformation and transportation of radioactive substances due to meteorological phenomena and other factors, provision of a think-tank function towards the recovery of the environment, conservation of research materials and samples and archiving of research methodologies and research objects. The key problems of the atmospheric radionuclide dynamics includes the research radionuclide transport in the atmospheric environment respectively, the terrestrial radionuclide dynamics - research radionuclide transfer and migration in the terrestrial environment, marine radionuclide dynamics - research radionuclide transfer in the marine environment and radiological hydrology - research radionuclide transfer from land to fresh water environments due to hydrological phenomena. The key radioecological transfer and effects include research radionuclide cycles in the forest ecosystems, research radionuclide transfer to biota in inland waters, research radionuclide transfer in soil-plant system, research biological effects of radiation exposure to microbes, algae, and plants, research biological effects of radiation exposure to animals, with an emphasis on free-ranging wildlife. The main purposes of modeling, measurements and forecasting approach include to evaluate and predict environmental radionuclide transfer and radiation through using computer simulations and other methods, to develop improved technologies to monitor and measure radiation, to develop mechatronics systems and remote control technologies that will enable sampling and other operations in areas where humans cannot approach, to make analysis and archiving of research outputs and research samples produced by IER and other institutes around the world. Provision of these materials to researchers around the world upon their request, to analyze and archive research outputs and research samples produced by IER and other institutes around the world and provide these materials to researchers around the world upon request.

Let us remind [1-3] that most of the models currently used to assess a state (as well as, the forecast) of an environment pollution are presently by the deterministic models or simplified ones, based on a simple statistical regressions. The success of these models, however, is limited by their inability to describe the nonlinear characteristics of the pollutant concentration behaviour and lack of under- 
standing of the involved physical and chemical processes Although the use of methods of a chaos theory establishes certain fundamental limitation on the long-term predictions, however, as has been shown in a series of our papers (see, for example, [1-11]), these methods can be successfully applied to a short-or medium-term forecasting. In Ref. [1-4] we presented the successful examples of the quantitatively correct description of the temporary changes in the pollutants concentration in a few atmospheric and hydroecological systems.

The main purpose of this paper is formally to represent theoretical basis of a new general formalism for an analysis and forecasting the environmental radioactivity dynamics, based on the methods of a chaos theory and dynamical systems. As an illustrative example, we make analysis of the radon concentration time series for 5 years (2003-2007) that can be considered a normal period and compared it with data from the precursory period of 2008 until March 2011, when the 2011 Tohoku-Oki Earthquake occurred. This analysis makes a purpose to reveal the chaotic features in the radon concentration series. This feature can be provided by atmospheric turbulence.

\section{NEW GENERAL FORMALISM FOR ANALYSIS OF AND FORECASTING THE ENVIRONMENTAL RA- DIACTIVITY DYNAMICS}

As usually, we start from the first key task on testing a chaos in the time series of environmental radioactivity dynamics. Following to [2-4], one should consider scalar measurements of the system dynamical parameter, say

$$
s(n)=s\left(t_{0}+n \Delta t\right)=s(n),
$$

Here $t_{0}$ is a start time, $\Delta t$ is the time step, and $n$ is number of the measurements. In a general case, $s(n)$ is any time series (environmental radioactive pollutants concentration). As processes resulting in a chaotic behaviour are fundamentally multivariate, one needs to reconstruct phase space using as well as possible information contained in $s(n)$. Such reconstruction results in set of $d$ dimensional vectors $\mathbf{y}(n)$ replacing scalar measurements. The main idea is that direct use of lagged variables $s(n+\tau)$, where $\tau$ is some integer to be defined, results in a coordinate system where a structure of orbits in phase space can be captured. Using a collection of time lags to create a vector in $d$ dimensions

$$
\mathbf{y}(n)=[s(n), s(n+\tau), s(n+2 \tau), . ., s(n+(d-1) \tau)],
$$

the required coordinates are provided. In a nonlinear system, $s(n+j \tau)$ are some unknown nonlinear combination of the actual physical variables. The dimension $d$ is the embedding dimension $d_{E}$ (see details, for example, in Refs [2-4]).

The choice of proper time lag is important for the subsequent reconstruction of phase space. If $\tau$ is chosen too small, then the coordinates $s(n+j \tau), s(n+(j+1) \tau)$ are so close to each other in numerical value that they cannot be distinguished from each other. If $\tau$ is too large, then $s(n+j \tau), s(n+(j+1) \tau)$ are completely independent of each other in a statistical sense. If $\tau$ is too small or too large, then the correlation dimension of attractor can be under-or overestimated.

Further it is an important task to choose some intermediate position between above cases. First approach is to compute the linear autocorrelation function $C_{L}(\delta)$ and to look for that time lag where $C_{L}(\delta)$ first passes through 0 . This gives a good hint of choice for $\tau$ at that $s(n+j \tau)$ and $s(n+(j+1) \tau)$ are linearly independent. It's better to use approach with a nonlinear concept of independence, e.g. an average mutual information [1-3]. The mutual information $I$ of two measurements $a_{i}$ and $b_{k}$ is symmetric and non-negative, and equals to 0 if only the systems are independent. The average mutual information between any value $a_{i}$ from system $A$ and $b_{k}$ from $B$ is the average over all possible measurements of $I_{A B}\left(a_{i}, b_{k}\right)$. Usually it is necessary to choose that $\tau$ where the first minimum of $I(\tau)$ occurs [2-4].

The goal of the embedding dimension determination is to reconstruct a Euclidean space $R^{d}$ large enough so that the set of points $d_{A}$ can be unfolded without ambiguity. The embedding dimension, $d_{E}$, must be greater, or at least equal, than a dimension of attractor, $d_{A}$, i.e. $d_{E}>d_{A}$. In other words, we can choose a fortiori large dimension $d_{E}$, e.g. 10 or 15 , since the previous analysis provides us prospects that the dynamics of our system is probably chaotic. The correlation integral analysis is one of the widely used techniques to investigate the signatures of chaos in a time series. The analysis uses the correlation integral, $C(r)$, to distinguish between chaotic and stochastic systems.

According to [2-4], one should calculate the correlation integral $C(r)$. If the time series is characterized by an attractor, then the correlation integral $C(r)$ is related to the radius $r$ as

$$
d=\lim _{\substack{r \rightarrow 0 \\ N \rightarrow \infty}} \frac{\log C(r)}{\log r},
$$

where $d$ is correlation exponent.

If the correlation exponent attains saturation with an increase in the embedding dimension, then the system is generally considered to exhibit chaotic dynamics. The saturation value of correlation exponent is defined as the correlation dimension $\left(d_{2}\right)$ of the attractor (see details in refs. $[3,4])$.

Another method for determining $d_{E}$ comes from asking the basic question addressed in the embedding theorem: when has one eliminated false crossing of the orbit with itself which arose by virtue of having projected the attractor into a too low dimensional space? [2-4]. In other words, when points in dimension $d$ are neighbours of one other? By examining this question in dimension one, then dimension two, etc. until there are no incorrect or false neighbours remaining, one should be able to establish, from geometrical consideration alone, a value for the necessary embedding dimension. Such an approach was described by Kennel et al. [16,17]. In dimension $d$ each vector $\mathbf{y}(k)$ has a nearest neighbour $\mathbf{y}^{N N}(k)$ with nearness 
in the sense of some distance function. The Euclidean distance in dimension $d$ between $\mathbf{y}(k)$ and $\mathbf{y}^{N N}(k)$ we call $R_{d}(k)[3]$

$$
\begin{aligned}
& R_{d}^{2}(k)=\left[s(k)-s^{N N}(k)\right]^{2}+\left[s(k+\tau)-s^{N N}(k+\tau)\right]^{2}+ \\
& \ldots+\left[s(k+\tau(d-1))-s^{N N}(k+\tau(d-1))\right]^{2} .
\end{aligned}
$$

$R_{d}(k)$ is presumably small when one has a lot a data, and for a dataset with $N$ measurements, this distance is of order $1 / N^{1 / d}$. In dimension $d+1$ this nearest-neighbour distance is changed due to the $(d+1)$ st coordinates $s(k+d \tau)$ and $s^{N N}(k+d \tau)$ to

$$
R_{d+1}^{2}(k)=R_{d}^{2}(k)+\left[s(k+d \tau)-s^{N N}(k+d \tau)\right]^{2} .
$$

We can define some threshold size $R_{T}$ to decide when neighbours are false. Then if [3]

$$
\frac{\left|s(k+d \tau)-s^{N N}(k+d \tau)\right|}{R_{d}(k)}>R_{T}
$$

the nearest neighbours at time point $k$ are declared false. Kennel et al. [17] showed that for values in the range $10 \leq R_{T} \leq 50$ the number of false neighbours identified by this criterion is constant. In practice, the percentage of false nearest neighbours is determined for each dimension $d$. A value at which the percentage is almost equal to zero can be considered as the embedding dimension.

As usually, the predictability can be estimated by the Kolmogorov entropy, which is proportional to a sum of positive Lyapunov exponents. The spectrum of the Lyapunov exponents is one of dynamical invariants for non-linear system with chaotic behaviour. The limited predictability of the chaos is quantified by the local and global Lyapunov exponents, which can be determined from measurements. The Lyapunov exponents are related to the eigenvalues of the linearized dynamics across the attractor. Negative values show stable behaviour while positive values show local unstable behaviour.

For chaotic systems, being both stable and unstable, Lyapunov exponents indicate the complexity of the dynamics. The largest positive value determines some average prediction limit. Since the Lyapunov exponents are defined as asymptotic average rates, they are independent of the initial conditions, and hence the choice of trajectory, and they do comprise an invariant measure of the attractor. An estimate of this measure is a sum of the positive Lyapunov exponents. The estimate of the attractor dimension is provided by the conjecture $d_{L}$ and the Lyapunov exponents are taken in descending order. The dimension $d_{L}$ gives values close to the dimension estimates discussed earlier and is preferable when estimating high dimensions.

If one computes the whole spectrum of the Lyapunov exponents, other invariants of the system, i.e. the Kolmogorov entropy and the attractor's dimension can be found. The Kolmogorov entropy measures the average rate at which information about the state is lost with time. An estimate of this measure is the sum of the positive Lyapunov exponents. The estimate of the dimension of the attractor is provided by the Kaplan and Yorke conjecture (see details in Refs. $[2-4,16,18]$ )

$$
d_{L}=j+\frac{\sum_{\alpha=1}^{j} \lambda_{\alpha}}{\left|\lambda_{j+1}\right|},
$$

where $j$ is such that $\sum_{\alpha=1}^{j} \lambda_{\alpha}>0$ and $\sum_{\alpha=1}^{j+1} \lambda_{\alpha}<0$, and the Lyapunov exponents are taken in descending order. The dimension $d_{L}$ gives values close to the dimension estimates discussed earlier and is preferable when estimating high dimensions. To compute the Lyapunov exponents, one should use a method with linear fitted map, although maps with higher order polynomials can be used too [18-23]. Another new approach has been recently developed by Glushkov-Prepelitsa et al and in using the neural networks technique [25].

\section{APPLICATION AND CONCLUSIONS}

Summing up above said and results of refs. [1-3], it is useful to summarize the key points of the investigating system for a chaos availability and wording the forecast model (evolution) for the environmental radioactivity dynamics. Naturally, a difference between the atmospheric and hydrological systems dynamics and the environmental radioactivity one is not essential and connected only with blocks of treating dynamics of these systems from the viewpoint of the evolutionary differential equations theory.

The above methods are just part of a large set of approaches (see our versions in [1-11]), which is used in the identification and analysis of chaotic regimes in the time series for the typical hydroecological systems. Shortly speaking, the whole technique of analysis, processing and forecasting any time series of the chemical pollutants in the typical hydroecological systems will be looked as follows (see figure below):

A). A general qualitative analysis of dynamical problem of the typical hydroecological systems (including a qualitative analysis from the viewpoint of ordinary differential equations, the "Arnold-analysis");

B) Checking for the presence of a chaotic (stochastic) features and regimes (the Gottwald-Melbourne's test; the method of correlation dimension);

C) Reducing the phase space (choice of the time delay, the definition of the embedding space by methods of correlation dimension algorithm and false nearest neighbor points);

D). Determination of the dynamic invariants of a chaotic system (computation of the global Lyapunov dimension $\lambda_{\alpha}$; determination of the Kaplan-York dimension $d_{L}$ and average limits of predictability $\operatorname{Pr}_{\max }$ on the basis of the advanced algorithms;

E) A non-linear prediction (forecasting) of a dynamical evolution of the system.

The last block indeed includes new methods and algo- 
rithms of nonlinear prediction such as methods of predicted trajectories, stochastic propagators and neural networks modelling, renorm-analysis with blocks of the polynominal approximations, wavelet-expansions $[10,11$, 25]). Indeed, one should use a few algorithms at any step of studying.

As an illustrative example, we make analysis of the radon concentration time series for 5 years (2003-2007) that can be considered a normal period and compared it with data from the precursory period of 2008 until March 2011, when the 2011 Tohoku-Oki Earthquake occurred. This analysis makes a purpose to reveal the chaotic features in the radon concentration series. This feature can be provided by atmospheric turbulence. In figure 1 we list the time-series variations of the radon concentrations [2628]. The downward arrow indicates the date of the 2011 Tohoku-Oki Earthquake in Japan. The light lines indicate the variations during the normal period, whereas the dark lines indicate the variations during the precursor period.

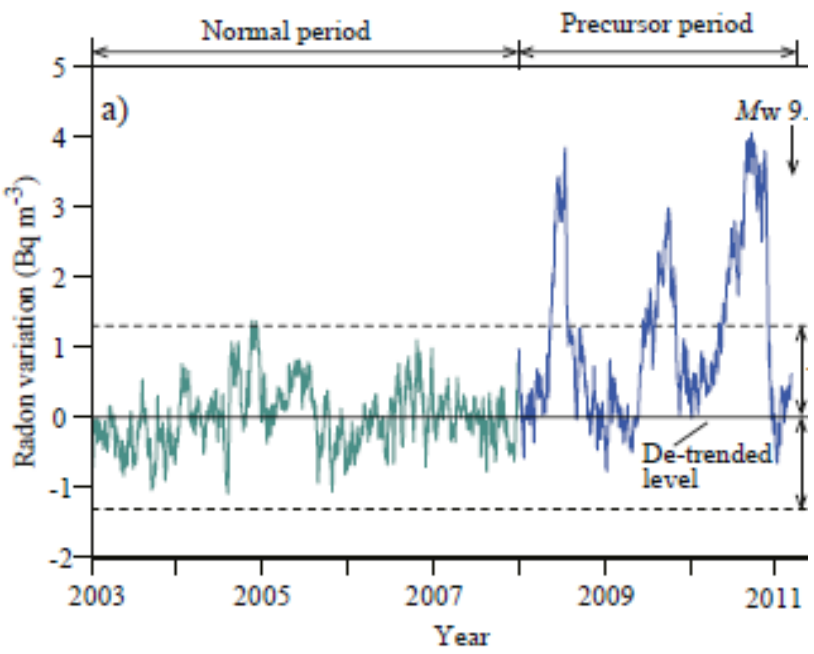

Fig. 1 - The time-series variations of the radon concentrations [26-28].

In Table 1 we list the results of preliminary analysis of the radon concentration time series (2003-2008 years; 8198 values), in particular, it summarizes the results of the numerical reconstruction of the attractors, as well as average limit of predictability $\left(P r_{\max }\right)$ and the GottwaldMelbourne chaos availability parameter $\mathrm{K}$ [8] for the radon concentrations.

Table 1 - Time lag $(\tau)$, correlation dimension $\left(d_{2}\right)$, embedding dimension $\left(d_{E}\right)$, Kaplan-Yorke dimension $\left(d_{L}\right)$, average limit of predictability $\left(P r_{\max }\right)$ and parameter $K$ for the radon concentrations.

\begin{tabular}{|l|l|l|c|l|l|}
\hline$\tau$ & $d_{2}$ & $d_{E}$ & $d_{L}$ & $P r_{\max }$ & $K$ \\
\hline 181 & 6,3 & 7 & 5,7 & 12 & 0,73 \\
\hline
\end{tabular}

At the same time, analysis and studying the radon concentrations time series during 2009-2011 does not definitely reveal the chaotic features that can be explained by insufficient series data. In any case this preliminary analysis has shown that the presented formalism can be used for adequate description of the environmental radioactivity dynamics.

\section{СПИСОК ЛИТЕРАТУРЫ}

1. Бунякова Ю.Я. Анализ и прогноз влияния антропогенных факторов на воздушной бассейн промышленного города / Ю.Я. Бунякова , А.В. Глушков. - Одесса: Экология, 2010.$256 \mathrm{c}$.

2. Глушков А.В. Низкоразмерный хаос в временных рядах концентраций загрязняющих веществ в атмосфере и гидросфере / А.В. Глушков, В.Н. Хохлов, Сербов Н.Г., Ю.Я. Бунякова, К. Балан, Е.Р. Баланюк. // Вестник Одесского государственного экологического университета.- 2007.-Вып.4.- С.337-348.

3. Glushkov A.V. Analysis and forecast of the anthropogenic impact on industrial city's atmosphere based on methods of chaos theory: new general scheme/ А.В. Глушков // Український гідрометеоророгічний журнал.-2014.-N 15.- С.32-36.

4. Khokhlov V.N., Glushkov A.V., Loboda N.S. Bunyakova Yu.Ya. Short-range forecast of atmospheric pollutants using non-linear prediction method. Atmospheric Environment. The Netherlands: Elsevier, 2008, vol.42, pp.7284-7292.

5. Glushkov A.V., Khokhlov V.N., Prepelitsa G.P., Tsenenko I.A. Temporal variability of the atmosphere ozone content: Effect of North-Atlantic oscillation. Optics of atmosphere and ocean, 2004, vol.14, no.7, pp.219-223.

6. Glushkov A.V., Loboda N.S., Khokhlov V.N. Using meteorological data for reconstruction of annual runoff series over an ungauged area: Empirical orthogonal functions approach to Moldova-Southwest Ukraine region. Atmospheric Research. Elseiver, 2005, vol.77, pp.100-113.

7. Glushkov A.V., Kuzakon' V.M., Khetselius O.Yu., Bunyakova Yu.Ya., Zaichko P.A. Geometry of Chaos: Consistent combined approach to treating chaotic dynamics atmospheric pollutants and its forecasting. Proceedings of International Geometry Center, 2013, vol.6, no.3, pp.6-13.

8. Glushkov A.V., Rusov V.N., Loboda N.S., Khetselius O.Yu., Khokhlov V.N., Svinarenko A.A., Prepelitsa G.P. On possible genesis of fractal dimensions in the turbulent pulsations of cosmic plasma - galactic-origin rays - turbulent pulsation in planetary atmosphere system. Adv. in Space Research. Elsevier, 2008, vol.42(9), pp.1614-1617.

9. Glushkov A.V., Loboda N.S., Khokhlov V.N., Lovett L. Using non-decimated wavelet decomposition to analyse time variations of North Atlantic Oscillation, eddy kinetic energy, and Ukrainian precipitation. Journal of Hydrology. Elseiver, 2006, vol.322, no. 1-4, pp.14-24

10. Glushkov A.V., Khetselius O.Yu., Brusentseva S.V., Zaichko P.A., Ternovsky V.B. Adv. in Neural Networks, Fuzzy Systems and Artificial Intelligence. Series: Recent Adv. in Computer Engineering. Gdansk: WSEAS, 2014, vol.21, pp.69-75. (Ed.: J. Balicki).

11. Glushkov A.V., Svinarenko A.A., Buyadzhi V.V., Zaichko P.A., Ternovsky V.B. Adv.in Neural Networks, Fuzzy Systems and Artificial Intelligence, Series: Recent Adv. in Computer Engineering. Gdansk: WSEAS, 2014, vol.21, pp. 143-150 (Ed.: J. Balicki).

12. Rusov V.D., Glushkov A.V., Vaschenko V.N., Myhalus O.T., Bondartchuk Yu.A. etal. Galactic cosmic rays - clouds effect and bifurcation model of the earth global climate. Part 1. Theory. Journal of Atmospheric and Solar-Terrestrial Physics. Elsevier, 2010, vol.72, pp.498-508.

13. Sivakumar B. Chaos theory in geophysics: past, present and future. Chaos, Solitons \& Fractals, 2004, vol.19, №2, pp.441-462.

14. Chelani A.B. Predicting chaotic time series of PM10 concentration using artificial neural network. Int. J. Environ. Stud, 2005, vol.62. №2, pp. 181-191.

15. Gottwald G.A., Melbourne I. A new test for chaos in deterministic systems. Proc. Roy. Soc. London. Ser. A. Mathemat. Phys. Sci., 2004, vol.460, pp.603-611.

16. Packard N.H., Crutchfield J.P., Farmer J.D., Shaw R.S. Geometry from a time series. Phys. Rev. Lett., 1980, vol.45, pp.712-716.

17. Kennel M., Brown R., Abarbanel H. Determining embedding dimension for phase-space reconstruction using a geometrical construction. Phys. Rev. A., 1992, vol.45, pp.3403-3411.

18. Abarbanel H.D.I., Brown R., Sidorowich J.J., Tsimring L.Sh. The analysis of observed chaotic data in physical systems. Rev. Mod. Phys, 1993, vol.65, pp.1331-1392.

19. Schreiber T. Interdisciplinary application of nonlinear time series methods. Phys. Rep., 1999, vol.308, pp.1-64. 
20. Fraser A.M., Swinney H. Independent coordinates for strange attractors from mutual information. Phys. Rev. A., 1986, vol.33, pp.1134-1140.

21. Grassberger P., Procaccia I. Measuring the strangeness of strange attractors. Physica D, 1983, vol.9, pp.189-208.

22. Gallager R.G. Information theory and reliable communication. NY: Wiley, 1968. 608 p.

23. Mañé R. On the dimensions of the compact invariant sets of certain non-linear maps. Dynamical systems and turbulence, Warwick 1980. Lecture Notes in Mathematics no.898. Berlin: Springer, 1981, pp.230-242. (Eds: D.A. Rand, L.S. Young).

24. Takens F. Detecting strange attractors in turbulence. Dynamical systems and turbulence, Warwick 1980. Lecture Notes in Mathematics no.898. Berlin: Springer, 1981, pp.366-381. (Eds D.A. Rand, L.S. Young).

25. Prepelitsa G.P., Glushkov A.V., Lepikh Ya.I., Buyadzhi V.V., Ternovsky V.B., Zaichko P.A. Chaotic dynamics of non-linear processes in atomic and molecular systems in electromagnetic field and semiconductor and fiber laser devices: new approaches, uniformity and charm of chaos. Sensor Electronics and Microsystems Techn., 2014, vol.11, no.4, pp.43-57.

26. Hayashi K., Yasuoka Y., Nagahama H. et al. Normal seasonal variations for atmospheric radon concentration: a sinusoidal model. Journ. of Env. Radiact., 2015, vol.139, pp.149-153.

27. Bossew P., Dubois G., Tollefsen T. Investigations on indoor radon in Austria, part 2: Geological classes as categorical externa drift for spatial modelling of the radon potential. J. Environ. Radioact., 2008, vol.99, pp.81-97.

28. Chambers S., Zahorowski W., Matsumoto K., Uematsu M. Seasonal variability of radon-derived fetch regions for Sado Island, Japan, based on 3 years of observations: 2002-2004. Atmos. Environ., 2009, vol.43, pp.271-279.

\section{REFERENCES}

1. Bunyakova Yu.Ya., Glushkov A.V. Analysis and forecast of the impact of anthropogenic factors on air basin of an industrial city. Odessa: Ecology, 2010. 256 p. (In Russian).

2. Glushkov A.V., Khokhlov V.N., Serbov N.G., Bunyakova Yu.Ya., Balan A.K., Balanyuk E.P. Low-dimensional chaos in the time series of concentrations of pollutants in an atmosphere and hydrosphere. Visn. Odes. derž. ekol. univ. - Bulletin of Odessa state environmental university, 2007, vol. 4, pp.337-348. (In Russian)

3. Glushkov A.V. Analysis and forecast of the anthropogenic impact on industrial city's atmosphere based on methods of chaos theory: new general scheme. Ukr. gidrometeorol. ž. - Ukranian hydrometeorological journal, 2014, no. 15, pp. 32-36.

4. Khokhlov V.N., Glushkov A.V., Loboda N.S., Bunyakova Yu.Ya Short-range forecast of atmospheric pollutants using non-linear prediction method. Atmospheric Environment. The Netherlands: Elsevier, 2008, vol.42, pp.7284-7292.

5. Glushkov A.V., Khokhlov V.N., Prepelitsa G.P., Tsenenko I.A. Temporal variability of the atmosphere ozone content: Effect of North-Atlantic oscillation. Optics of atmosphere and ocean, 2004, vol.14, no.7, pp.219-223.

6. Glushkov A.V., Loboda N.S., Khokhlov V.N. Using meteorological data for reconstruction of annual runoff series over an ungauged area: Empirical orthogonal functions approach to MoldovaSouthwest Ukraine region. Atmospheric Research. Elseiver, 2005, vol.77, pp.100-113.

7. Glushkov A.V., Kuzakon' V.M., Khetselius O.Yu., Bunyakova Yu.Ya., Zaichko P.A. Geometry of Chaos: Consistent combined approach to treating chaotic dynamics atmospheric pollutants and its forecasting. Proceedings of International Geometry Center, 2013, vol.6, no.3, pp.6-13.

8. Glushkov A.V., Rusov V.N., Loboda N.S., Khetselius O.Yu., Khokhlov V.N., Svinarenko A.A., Prepelitsa G.P. On possible genesis of fractal dimensions in the turbulent pulsations of cosmic plasma - galactic-origin rays - turbulent pulsation in planetary atmosphere system. Adv. in Space Research. Elsevier, 2008, vol.42(9), pp.1614-1617.

9. Glushkov A.V., Loboda N.S., Khokhlov V.N., Lovett L. Using non-decimated wavelet decomposition to analyse time variations of North Atlantic Oscillation, eddy kinetic energy, and Ukrainian precipitation. Journal of Hydrology. Elseiver, 2006, vol.322, no. 1-4, pp.14-24.

10. Glushkov A.V., Khetselius O.Yu., Brusentseva S.V., Zaichko P.A., Ternovsky V.B. Adv. in Neural Networks, Fuzzy Systems and Artificial Intelligence. Series: Recent Adv. in Computer Engineering. Gdansk: WSEAS, 2014, vol.21, pp.69-75. (Ed.: J. Balicki).

11. Glushkov A.V., Svinarenko A.A., Buyadzhi V.V, Zaichko P.A. Ternovsky V.B. Adv.in Neural Networks, Fuzzy Systems and Artificial Intelligence, Series: Recent Adv. in Computer Engineering. Gdansk: WSEAS, 2014, vol.21, pp. 143-150 (Ed.: J. Balicki).

12. Rusov V.D., Glushkov A.V., Vaschenko V.N., Myhalus O.T., Bondartchuk Yu.A. etal. Galactic cosmic rays - clouds effect and bifurcation model of the earth global climate. Part 1. Theory. Journal of Atmospheric and Solar-Terrestrial Physics. Elsevier, 2010, vol.72, pp.498-508.

13. Sivakumar B. Chaos theory in geophysics: past, present and future. Chaos, Solitons \& Fractals, 2004, vol.19, №2, pp.441-462.

14. Chelani A.B. Predicting chaotic time series of PM10 concentration using artificial neural network. Int. J. Environ. Stud, 2005, vol.62. №2, pp. 181-191.

15. Gottwald G.A., Melbourne I. A new test for chaos in deterministic systems. Proc. Roy. Soc. London. Ser. A. Mathemat. Phys. Sci., 2004, vol.460, pp.603-611.

16. Packard N.H., Crutchfield J.P., Farmer J.D., Shaw R.S. Geometry from a time series. Phys. Rev. Lett., 1980, vol.45, pp.712-716.

17. Kennel M., Brown R., Abarbanel H. Determining embedding dimension for phase-space reconstruction using a geometrical construction. Phys. Rev. A., 1992, vol.45, pp.3403-3411.

18. Abarbanel H.D.I., Brown R., Sidorowich J.J., Tsimring L.Sh. The analysis of observed chaotic data in physical systems. Rev. Mod. Phys, 1993, vol.65, pp.1331-1392.

19. Schreiber T. Interdisciplinary application of nonlinear time series methods. Phys. Rep., 1999, vol.308, pp.1-64.

20. Fraser A.M., Swinney H. Independent coordinates for strange attractors from mutual information. Phys. Rev. A., 1986, vol.33, pp.1134-1140.

21. Grassberger P., Procaccia I. Measuring the strangeness of strange attractors. Physica D, 1983, vol.9, pp.189-208.

22. Gallager R.G. Information theory and reliable communication. NY: Wiley, 1968. 608 p.

23. Mañé R. On the dimensions of the compact invariant sets of certain non-linear maps. Dynamical systems and turbulence, Warwick 1980. Lecture Notes in Mathematics no.898. Berlin: Springer, 1981, pp.230-242. (Eds: D.A. Rand, L.S. Young).

24. Takens F. Detecting strange attractors in turbulence. Dynamical systems and turbulence, Warwick 1980. Lecture Notes in Mathematics no.898. Berlin: Springer, 1981, pp.366-381. (Eds: D.A. Rand, L.S. Young).

25. Prepelitsa G.P., Glushkov A.V., Lepikh Ya.I., Buyadzhi V.V., Ternovsky V.B., Zaichko P.A. Chaotic dynamics of non-linear processes in atomic and molecular systems in electromagnetic field and semiconductor and fiber laser devices: new approaches, uniformity and charm of chaos. Sensor Electronics and Microsystems Techn., 2014, vol.11, no.4, pp.43-57.

26. Hayashi K., Yasuoka Y., Nagahama H. et al. Normal seasona variations for atmospheric radon concentration: a sinusoidal model. Journ. of Env. Radiact., 2015, vol.139, pp.149-153.

27. Bossew P., Dubois G., Tollefsen T. Investigations on indoor radon in Austria, part 2: Geological classes as categorical external drift for spatial modelling of the radon potential. J. Environ. Radioact., 2008, vol.99, pp.81-97

28. Chambers S., Zahorowski W., Matsumoto K., Uematsu M. Seasonal variability of radon-derived fetch regions for Sado Island, Japan, based on 3 years of observations: 2002-2004. Atmos. Environ., 2009, vol.43, pp.271-279. 


\title{
АНАЛИЗ И ПРОГНОЗ ДИНАМИКИ РАДИОАКТИВНОСТИ ОКРУЖАЮЩЕЙ СРЕДЫ ОСНО- ВАННЫЙ НА МЕТОДАХ ТЕОРИИ ХАОСА: ОБЩАЯ СХЕМА И НЕКОТОРЫЕ ПРИМЕНЕНИЯ
}

\author{
А.В. Глушков, д-р ф.-м. н., проф. \\ Е.Р. Губанова, д-р экон. Н., проф., О.Ю. Хецелиус, д-р ф.-м. н., проф., \\ Г.П. Препелица, д-р ф.-м. Н., проф., А.А. Свинаренко, д-р ф.-м. Н., проф., \\ Ю.Я. Бунякова, к.геогр. н., доц., В.В. Буяджи, ассист.
}

Одесский государственный экологический университет, ул. Львовская,15 ,65016, Одесса, Украина,glushkovav@gmail.com

\begin{abstract}
Мы представляем новый общий аппарат анализа, обработки и прогнозирования характеристик временных рядов концентраций загрязняющих веществ для типовых гидроэкологических систем, схематично включает следующие блоки и уровне исследований: общий качественный анализ динамических особенностей задачи эволюции типичных гидроэкологических систем (в том числе, качественный анализ с точки зрения обыкновенных дифференциальных уравнений, "Арнольд-анализ»); б) проверка на наличие хаотических (стохастических) особенностей, элементов, режимов (тест ГотвальдаМельбурна, метод корреляционной размерности); в) исследование фазового пространства (выбор времени задержки, определение пространства вложения методами и алгоритмами корреляционной размерности и ложных ближайших соседних точек); г) определение динамических инвариантов хаотической системы (вычисление глобальной размерности, показателей Ляпунова $\lambda_{\alpha}$; определение размерности Каплана-Йорка $d_{L}$ и среднего предела предсказуемости $P r_{\max }$ на основе усовершенствованных алгоритмов; е) нелинейный анализ и предсказание (прогнозирование ) динамической эволюции систем. Последний блок действительно включает в себя новые (в динамике радиоактивности окружающей среды) методы и алгоритмы нелинейного прогнозирования, такие как методы прогнозируемых траекторий, формализм случайных пропагаторов, нейросетевые алгоритмы, ренорм-анализ с блоками полиномиальных аппроксимаций, вейвлет-разложений и т.д.

Ключевые слова: динамика радиоактивного загрязнения окружающей среды, экологическое состояние, временные ряды концентраций, загрязняющие вещества, анализ и прогнозирование на основе методов теории хаоса.
\end{abstract}

\section{АНАЛІЗ І ПРОГНОЗ ДИНАМІКИ РАДІОАКТИВНОСТІ НАВКОЛИШНЬОГО СЕРЕДОВИЩА ЗАСНОВАНИЙ НА МЕТОДАХ ТЕОРІЯ ХАОСУ: ЗАГАЛЬНА СХЕМА І ДЕЯКІ ЗАСТОСУВАННЯ}

О.В. Глушков, д-р ф.-м. н., проф. , О.Р. Губанова, д-р екон. н., проф., О.Ю. Хецеліус, д-р ф.-м. н., проф., Г.П. Препелиця, д-р ф.-м. н., проф., А.А. Свинаренко, д-р ф.-м. н., проф., Ю.Я. Бунякова, к.геогр. н., доц., В.В. Буяджи, асист.

Одеський державний екологічний університет, вул. Львівська, 15, 65016 Одеса, Украӥна, glushkovav@gmail.com

Ми представляємо новий загальний апарат аналізу, обробки та прогнозування характеристик часових рядів концентрацій забруднюючих речовин для типових гідроекологічних систем, що схематично включає наступні блоки і рівні досліджень: а) загальний якісний аналіз динамічних особливостей завдання еволюції типових гідроекологічних систем (у тому числі, якісний аналіз з погляду звичайних диференціальних рівнянь ", Арнольд-аналіз»); б) перевірку на наявність хаотичних (стохастичних) особливостей, елементів, режимів (тест Готвальда-Мельбурна, метод кореляційної розмірності); в) дослідження фазового простору (вибір часу затримки, визначення простору вкладення методами $\mathrm{i}$ алгоритмами кореляційної розмірності і помилкових найближчих сусідніх точках) ;. г) визначення динамічних інваріантів хаотичної системи (обчислення глобальної розмірності, показників Ляпунова $\lambda_{\alpha}$; визначення розмірності Каплана-Йорка $d_{L}$ і середнього межі передбачуваності $P r_{\max }$ на основі вдосконалених алгоритмів ;. е) нелінійний аналіз і прогноз (прогнозування) динамічної еволюції систем. Останній блок дійсно включає в себе нові (в динаміці радіоактивного забруднення навколишнього середовища) методи та алгоритми нелінійного прогнозування , такі як методи прогнозованих траєкторій, формалізм випадкових пропагатор, нейромережеві алгоритми, ренорм-аналіз з блоками поліноміальних апроксимацій, вейвлет-розкладів і т.д.

Ключові слова: динаміка радіоактивного забруднення навколишнього середовища, екологічний стан, часові ряди концентрацій, забруднюючі речовини, аналіз та прогнозування на основі методів теopiï xaocy. 